\title{
ARTE POP E BIZANTINA NA ICONOGRAFIA CARISMÁTICA ${ }^{1}$
}

\section{Evandro Bonfim ${ }^{2}$}

Resumo: O objetivo deste artigo é buscar entender o lugar das referências iconográficas da comunidade carismática católica Canção Nova na proposta de experiência cristã com base na ação do Espírito Santo mantida pelo coletivo. As imagens ilustrando a iconografia Canção Nova foram fotografadas pessoalmente nas diversas dependências da comunidade (lojas, salóes dos grupos de oração, complexo da Chácara Santa Cruz, estúdios, capelas) visitadas ao longo da pesquisa de campo e no material gráfico dos produtos em comunicação do grupo. Dois registros artísticos servem de referência para a composição do discurso visual deles: o Bizantino e a Pop Arte. A hipótese a ser trabalhada é de que tais estilos são condizentes com a proposta de Cristianismo do coletivo carismático, baseada nos temas da inovação, em relação a outras formas de praticar o catolicismo, e da transmissáo de fluxos espirituais, com destaque para o preenchimento pelo Espírito Santo.

Palavras-chave: Carismas Tecnológicos; Arte Pop; Arte Bizantina; Cristianismo.

$$
\begin{array}{r}
\text { POP AND BYZANTINE ART REFERENCES IN BRAZILIAN CHARISMATIC } \\
\text { ICONOGRAPHY }
\end{array}
$$

\begin{abstract}
The article looks after to understand the place of the iconographic references of the Catholic charismatic community Canção Nova in the proposal of Christian experience based on the action of the Holy Spirit. The images illustrating the Canção Nova iconography were photographed in person in the various facilities of the community (shops, halls of prayer groups, Chácara Santa Cruz complex, studios, chapels) visited during the field research and in the graphic material of the products in communication of the group. Two artistic frameworks are reference
\end{abstract}

${ }^{1}$ Como citar: : BONFIM, Evandro. Arte Pop na Iconografia Carismática. Debates do NER, Porto Alegre, ano 21, n. 39, p. 263-292, 2021.

2 Bolsista de Pós-Doutorado da Fundação de Amparo à Pesquisa do Estado de São Paulo (2015/26464-90). E-mail: evandrobonfim@hotmail.com. ORCID: https://orcid. org/0000-0002-0459-928X. 
for the composition of their visual discourse: the Byzantine and Pop Art. The hypothesis to be worked on is that such styles are consistent with the Christian experience proposed by the group, based on the themes of innovation, in relation to other ways of practicing Catholicism, and of the transmission of spiritual flows, with emphasis on the filling by Holy Spirit.

Keywords: Technological Spiritual Gifts; Pop Art; Byzantine art; Christianity.

\section{INTRODUÇÃO}

Estudos como o de Erwin Panofsky (2001) sobre as relaçôes entre a Escolástica e a Arquitetura Gótica mostram como as concepçôes cristâs podem ganhar materialidade pictórica e arquitetônica, possibilitando, no caso discutido pelo autor, a apreensão pelos leigos da intricada cosmologia da Igreja Católica medieval. De maneira similar, propostas contemporâneas de Cristianismo adotam certas referências estéticas, como a combinação de iconografias de escolas artísticas diversas, com o intuito de promover conteúdos e experiências condizentes com o tipo de manifestação cristã que propóem.

A partir de tal chave, o presente artigo está interessado nas expressões icônicas encontradas pelo público que frequenta os eventos e tem acesso aos livros, material audiovisual e programas da Comunidade Canção Nova, que se deparam com configuraçôes artísticas ecléticas ilustrando a versão carismática da mensagem cristã. Primeiramente, serão apresentadas as principais caraterísticas da comunidade católica, apontando para a convergência entre as práticas litúrgicas e evangelizadoras do coletivo e a promoção da pessoa cristã pneumática. Depois, se examinará mais atentamente os referenciais iconográficos presentes em diversas dependências da Canção Novas no Sudeste brasileiro, a partir de imagens fotografadas pelo autor durante pesquisa de campo entre 2009-2010. A análise que se segue vai mostrar 
como as preferências visuais Canção Nova estão entre as variadas provisões rituais que visam a abertura para a experiência com o Espírito Santo.

A Canção Nova é uma comunidade da Renovação Carismática Católica que surgiu no Vale do Paraíba paulista no final da década de 1970. Faz parte do ramo não-cessacionista do Cristianismo, ou seja, o grupo se conforma a partir do que seria a ação hodierna do Espírito Santo, manifesta mediante dons, sendo Canção Nova também o nome de um carisma específico que habilita os integrantes a operar os meios de comunicação com eficácia técnica e sobrenatural. $\mathrm{O}$ artigo apresenta imagens coletadas pessoalmente e autorizada pela comunidade em dependências do grupo nas cidades de Queluz (casa de formação), Cachoeira Paulista (sede) e Rio de Janeiro (estação de rádio).

Em etnografia sobre a transmissão de dons, pessoas espirituais e mensagens pela Canção Nova (Bonfim, 2012), destacamos que a ênfase na missão mediante a transferência pneumática como forma não-verbal de testemunho (Bonfim, 2016) e principal ritual de constituição da pessoa cristã aponta para concepçóes de Cristianismo que escapam aos paradigmas da intimidade, da interioridade e da individualidade que caracterizam os textos clássicos sobre a religião (Dumont, 2000 Mauss, 2003) e discussóes correntes da chamada Antropologia do Cristianismo (Robbins, 2004; Vilaça, 2008). As formas de experiência espiritual promovidas por características formais dos elementos artísticos que serão apresentados no decorrer do artigo são solidárias com outras provisóes da comunidade Canção Nova. como as missas voltadas para a descida do Espírito Santo, as práticas generalizadas de compartilhamento paraclético via imposição de mãos como forma de boas-vindas, exorcismo, cura e acompanhamento para oração, as capacidades multifacetadas da glossolalia, que serve de índice tanto da presença quanto do transbordamento do Espírito Santo e produz efeitos espirituais de expulsão de forças demoníacas, entendimentos proféticos e propriedades sanativas, dentre outras.

Inclusive, fenômenos como a glossolalia, embora geralmente presentes nas etnografias (sobretudo do Pentecostalismo), contam com reduzida descrição 
dos aspectos linguísticos formais e em termos de ideologia linguística, que, no caso da "língua dos anjos" tem como moção principal a manifestação da alteridade (Bonfim, 2015). Isto ocorre principalmente em comparação aos trabalhos sobre a tradução da Bíblia e a projeção de categorias ocidentais como o indivíduo, mostrando o desequilíbrio nos investimentos analíticos mesmo de práticas centrais dos cristianismos mais discutidos pela recente literatura antropológica, gerando lacunas que poderiam encetar outras possibilidades de se interpretar e definir a noção de pessoa cristã (ver Bialecki e Daswani, 2015, sobretudo sobre a inflexão melanésia do debate).

Desta forma, todas as práticas enfeixadas na experiência cristã da Canção Nova corroboram para o movimento de externalidade do tipo de cristianismo praticado e de porosidade da pessoa cristã envolvida, que não se fragmenta com a experiência, como pensam autores como Csordas (1997a e 1997b), mas, antes, se conforma pelos trânsitos dos constituintes espirituais, ressaltando o aspecto transformativo que caracteriza o discurso religioso. Assim, o artigo se insere na discussão proposta por Bruno Latour sobre "a existência de formas de discurso - novamente, não se trata apenas de linguagem - que sejam capazes de transmitir pessoas e não informação: seja porque produzem em parte as pessoas, ou porque novos estados - 'novos começos', como diria William James - se produzem nas pessoas a quem esse tipo de fala se dirige" (2004, p. 352). Voltemo-nos então para o discurso religioso pictórico mobilizado pela Cançáo Nova.

É interessante que as referências visuais da Canção Nova correspondam a dois estilos que estáo quase em pontos extremos na escala do tempo na história da arte, segundo o cânone ocidental. O estilo bizantino começa a se formar na Antiguidade tardia, após a conversão de Constantino (primeiro quartel do século IV), avançando pela Idade Média nos territórios do Império Oriental, enquanto a Pop Arte está entre os desenvolvimentos artísticos mais recentes do mundo contemporâneo, tendo como período de maior notoriedade os anos entre 1960 e 1990. A escolha de tais repertórios iconográficos pela comunidade carismática parece ocorrer em afastamento das visualidades mais marcantes da Igreja Católica brasileira: a herança do 
Cristianismo medieval e a estética/mentalidade barroca, elementos bastante presentes no Catolicismo popular.

Tal contraponto icônico não se realiza, no entanto, segundo os moldes críticos do Protestantismo, que pretende despir o Cristianismo da profusão de imagens que caracterizariam os templos pagãos, nem de certas tendências dentro do Catolicismo contemporâneo que procuram minimizar os sinais exteriores de devoção e hierofania para focar na experiência interiorizada e na dimensão sócio-política da mensagem cristã. Mas quais as características dos dois estilos artísticos são solidárias com o tipo de Cristianismo proposto pela Canção Nova, de forma a ilustrar os principais elementos definidores da comunidade através de peças discursivas visuais? A pergunta começará a ser respondida pelo conjunto iconográfico dominante nos cenários de eventos massivos e dos estúdios do grupo, a Arte Bizantina.

\section{A PERSPECTIVA INVERTIDA COMO PROJEÇÃO DO PNEUMA}

O estilo Bizantino pode ser considerado a referência visual que busca expressar a novidade do Cristianismo ao se instalar nas estruturas sociais e políticas da Antiguidade romana. O que se convenciona chamar de Arte Bizantina surge para atender à seguinte questão: como devem ser a arquitetura e a visualidade do culto cristão, que acaba de se tornar evento público, destinado a todos os setores do mundo romano, das elites dirigentes às multidóes citadinas? Gombrich coloca nos seguintes termos o desafio estético enfrentado pelo Cristianismo da época:

Quando, no ano de 311 d.C., o imperador Constantino estabeleceu a Igreja Cristã como um poder de Estado, os problemas com que se defrontou foram enormes. Durante os períodos de perseguição não houvera necessidade nem, de fato, possibilidade de construir lugares públicos de culto. As igrejas e salas de reuniâo que existiam eram pequenas e de aspecto insignificante. Mas quando a Igreja passou a ser o poder supremo do reino, todo o seu relacionamento com a arte teve, necessariamente, que ser reexaminado. Os lugares de culto não 
podiam adotar por modelos os antigos templos, uma vez que sua função era inteiramente diferente. $\mathrm{O}$ interior do templo era, usualmente, um pequeno sacrário para abrigar a estátua de um deus. As procissóes e os desfiles tinham lugar no lado de fora. A igreja, pelo contrário, tinha que reservar espaço para toda a congregação que se reunia a fim de assistir ao serviço religioso, quando o padre recitava a missa no altar-mor ou proferia seu sermão. Assim, aconteceu que as igrejas não usaram os templos pagáos como seus modelos, mas adotaram o tipo de amplos salóes que, em tempos clássicos, eram conhecidos pelo nome de "basílica", o que significa aproximadamente "pórtico real" (Gombrich, 1999, p. 84, grifo meu).

Assim, o estilo Bizantino pode ser chamado de uma arte do "novo", visto que não podia tomar como inspiração nem as estruturas do passado criptocristão nem as do acervo pagão, isto porque a situação comunicativa com a qual o Cristianismo se deparava não podia ser contemplada por tais modelos. O método praticamente boca a boca de repasse da mensagem evangélica e as assembleias clandestinas correntes nos anos heroicos da perseguição dão lugar a outra configuração de relações entre culto cristão e poder temporal, em que o Cristianismo deveria ser comunicado para o grande público que compunha o Império Romano. Os templos pagãos, não somente por razôes religiosas, mas também por motivos estruturais, não davam conta de atender aos objetivos de reunião e transmissão do novo Cristianismo emergente, promovido pelo próprio imperador. É notável que a arquitetura civil romana forneceu a solução mais adequada para comportar a igreja cristã, em sentido amplo. Tais questóes são absolutamente pertinentes para a Canção Nova, que se propóe evangelizar as massas e acolher pessoas para eventos religiosos multitudinários em estruturas arquitetônicas que seguem o modelo de construçôes civis, como os ginásios esportivos (no qual se baseiam os "rincóes" onde acontecem os eventos da comunidade).

Assim, ao tomar a arte Bizantina como uma de suas principais referências visuais, a Canção Nova realiza um gesto discursivo visual similar ao da igreja cristã pós-Constantino, que assim estabelecia de forma pública a novidade do Cristianismo no mundo romano, sem conexôes com os marcos 
estéticos religiosos precedentes, estabelecendo-se como culto autorizado (e depois oficial) do Império. A dimensão política atual da retomada do bizantino pela Canção Nova, conforme ressaltado acima, diz respeito a se diferenciar da própria matriz católica sem recorrer a outras fontes críticas que combatem diretamente o Vaticano, a saber, o protestantismo e certos críticos internos do Catolicismo, como a Teologia da Libertação.

No entanto, a emulação do significado político do surgimento do estilo bizantino não parece ser mais importante do que a concepção de irrupção do sagrado contida em tal proposta estética, extremamente solidária às ideias-valor da Canção Nova demonstradas, por exemplo, nas formas rituais. Em primeiro lugar, é necessário dizer que a arte bizantina não se propóe à representação, mas à manifestação ou revelação do divino, que é capaz de se apresentar e se deixar ser localizado através de formas apreensíveis aos sentidos. A referência visual máxima da arte do Império Romano do Oriente é a própria encarnação do Cristo, ou seja, a manifestação imagética e material da pessoa divina invisível, tal como descrita pelo apóstolo Paulo: "Ele, existindo em forma divina, não se apegou ao ser igual a Deus, mas despojou-se, assumindo a forma de escravo e tornando-se semelhante ao ser humano. E encontrado em aspecto humano, humilhou-se, fazendo-se obediente até a morte" (Filipenses 2:6-8). Esta transfiguração da divindade em humanidade é chamada em grego bizantino de kenosis. Assim, o verbo divino ao se fazer carne, também se fez imagem.

Com tal ponto de partida, a arte bizantina, sobretudo a expressa através dos ícones, vai buscar as manifestaçôes da pessoa divina do Cristo através de certos tipos especiais de imagens, conhecidas como acheropoites, ou seja, que não foram feitas por mãos humanas. Não se tratava de imagens criadas por artífices para tentar imaginar as feiçóes do Cristo, mas sim o próprio semblante de Jesus tal como revelado por ele mesmo e impresso em suportes materiais. Esta concepção contornaria justamente o problema do fetichismo, quando o objeto ganha agência própria diante do humano que o fez, posto que a mediação humana está aqui eclipsada. No mundo oriental, será a imagem de Edessa (Mandylion), concedida pelo Filho de Deus ao rei Abgar, 
um contemporâneo dos eventos evangélicos, o modelo para a figuração do Cristo nos ícones. O correspondente latino da "imagem não feita por mãos humanas" seria o sudário de Turim e a Sagrada Face do véu de Verônica.

As capacidades sagradas do ícone bizantino não vinham apenas do estatuto teológico da imagem, ou seja, da possibilidade de figurar a pessoa divina por causa da kenosis e das revelaçôes da aparência divina através das acheropoites (cláusulas simplesmente não encontradas ou admitidas por judeus e muçulmanos, duas posições críticas das concepções cristãs de imagem durante o desenvolvimento do estilo bizantino). A imagem também possui estatuto ontológico próprio. Isto porque a pessoa, na época de constituição da arte bizantina, não estava limitada ao corpo, mas se estendia a todos os objetos que lhe pertenciam e se fazia presente, sobretudo, nas figurações que se fazia dela. Por exemplo, no culto imperial, ter a imagem do imperador significava ter o próprio imperador em casa, visto que as características que definiam aquela pessoa podiam ser encontradas em ambas as instâncias, tanto a corporal quanto a imagética.

Tal concepção de pessoa, distribuída em vários tipos de materialidade (corpo, objetos, imagens) e extensível por meios tangíveis até quase à ubiquidade, faz com que a imagem do Jesus bizantino praticamente equivalha à presença real de Cristo, como na Eucaristia. Tanto que alguns sacerdotes bizantinos chegavam a raspar os ícones para misturar o pó ao vinho, como se o resíduo fosse a terceira espécie na qual o Filho de Deus se transubstanciaria na missa.

Os estatutos teológico e ontológico da imagem bizantina serviam de sustentáculo para a intenção maior da arte do Cristianismo oriental: oferecer às pessoas que se reuniam nos templos cristãos a visão dos "céus abertos". Diferentemente do Gótico, que compartilhava dos objetivos didáticos da Escolástica, como mostra Panofsky, o estilo bizantino não buscava ensinar os conteúdos bíblicos à população iletrada (outra justificativa comum do uso das imagens pelos cristãos, especialmente defendida por São Tomás de Aquino), mas oferecer ao público a oportunidade de entrar em contato com o mundo espiritual, que abria brecha na realidade mundana através dos céus 
físicos, tal como acontecera por ocasião do batismo de Jesus e São Estevão experimentara durante o martírio por lapidação. As pinturas bizantinas, conforme bem coloca Gombrich, eram consideradas pelos iconófilos do período como "reflexos misteriosos do mundo sobrenatural" (1999, p. 88).

O que se desejava comunicar no Cristianismo Bizantino, portanto, não eram conteúdos, mas determinada experiência com o sobrenatural, que dependia, conforme dito, de certa noção de pessoa cuja materialidade não se restringe ao corpo, visto que a pessoalidade se transmite para coisas tocadas (o que vai dar origem às relíquias de contato) e está igualmente presente nas imagens, em que não existe a diferença entre retrato e retratado, mas somente entre as substâncias em que determinado conjunto de caracteres (a pessoa) encontra registro visual e concretude.

Tais concepções são extremamente afins com o Cristianismo da Canção Nova, que propóe igualmente como evangelização a experiência com as pessoas divinas (Cristo e o Espírito Santo) mais do que o repasse de conteúdo. O modelo de evangelização da comunidade também só se faz possível se determinada noção de pessoa, ou seja, certa “ontologia”, estiver ativa, pois a experiência da movimentação espiritual (libertação e efusão) e da troca de dons entre seres humanos e com a sobrenatureza pressupóe corpos porosos, em constante reconfiguração e constituídos por elementos exteriores, conforme pode ser visto na noção de testemunho por parresia (Bonfim, 2016).

Neste aspecto, a Arte Bizantina incorporava a inovação teológica trazida pelo Cristianismo no que diz respeito à concepção de alma, conforme mostra Besançon no instigante livro "A Imagem Proibida: a história intelectual da Iconoclastia":

As imagens cristãs participam do clima geral da arte que passou, entre os séculos II e IV, por uma reorientação profunda. (...) Correlatamente enriquece-se a noçáo de alma. Esta, de fato, não é encerrada em sua relaçáo com o corpo, uma vez que pode abrir-se às influências divinas. O homem tem seu corpo, pode viver de acordo com as exigências de sua alma, mas pode receber o Espírito, o sopro pneumático que faz dele um "homem novo", para falar como Sáo 
Paulo, que neste ponto responde a uma preocupação comum da filosofia e do movimento religioso universal (Besançon, 1997, p.183. Grifos do autor).

A composição das imagens bizantinas buscava justamente a transmissão da pessoalidade divina proporcionada ou mesmo contida nos ícones e mosaicos para as pessoas que os observavam. Para tanto, os artistas lançavam mão de recursos que se mostraram contrários aos desenvolvimentos posteriores da arte ocidental como a perspectiva, considerada fator de progresso para a técnica da pintura. Propositadamente, os artistas bizantinos usavam a perspectiva invertida. Ou seja, em vez do olhar do observador entrar no interior do quadro percorrendo a profundidade pictórica, são os elementos pintados que se projetam como que para dentro daqueles que os estão observando. Como bem coloca Besançon, na espiritualidade bizantina, que é artística,

o vulto e o relevo tornariam pesada a figura e a encerrariam na matéria. No mosaico, os corpos, representados num só plano, já não têm volume nem peso, não são solidários com a parede, flutuam num espaço espiritual magnificado pela cor. Esta se mostra impregnada de luz (Besançon, 1997, p.184).

É como se as imagens não tivessem qualquer densidade em si, como as estátuas representando os santos, encontrando corporeidade somente nos observadores, nos quais se projeta e preenche. É importante não perder de vista que tais opçóes técnicas não são usadas primariamente para realizar certos efeitos de sentido exprimindo concepçôes teológicas, mas para promover comunicaçóes espirituais que se desejam efetivas e reais. A composição dos elementos busca a criaçáo de canais físicos para o extravasamento concreto das pessoas sagradas transubstanciadas nos quadros, e não a produção da sensação estética da qual tal irrupção divina estivesse ocorrendo. Não se pode tomar a visão das imagens bizantinas como experiência psicológica nem simbólica, mas primariamente corpórea, ocorrendo entre pessoas humanas e divinas. 
O manejo da luz segue a mesma proposta da perspectiva invertida. Não há luzes que se projetam a partir de determinado foco para iluminar seletivamente o quadro. São as figuras sagradas as próprias fontes de luz, que a irradiam para fora da cena em que elas estão em direção ao espectador. Isto faz com que a luz presente na imagem não produza sombras. $\mathrm{O}$ dourado característico do estilo bizantino não é uma cor, mas, precisamente, a luz própria portada e emanada, por exemplo, pelo ícone.

A iconografia bizantina se faz presente na Canção Nova com maior destaque no principal espaço ritual-comunicativo do grupo: os palcos localizados nos estúdios e nos rincôes, que servem, ao mesmo tempo, de cenário para os programas da TV CN e altar para as missas. No momento da pesquisa, a comunidade ainda não tinha igrejas, mas somente capelas e ermidas de pequeno porte. Embora, atualmente (por pressão da Diocese de Lorena), a comunidade conte com o Santuário do Pai das Misericórdias, no formato de templo católico tradicional, a maior parte dos eventos religiosos acontece em estruturas híbridas, adaptadas tanto à difusáo massiva quanto às necessidades litúrgicas. Isto faz com que componentes sacros obrigatórios na configuração do altar católico disputem espaço com monitores, caixas de som, pedestais para microfone, instrumentos musicais e refletores. Os únicos elementos religiosos que parecem se sobressair são os imensos painéis com o Cristo e a Virgem Bizantinos, como pode ser visto abaixo em fotografia referente ao Novo Rincão da Chácara Santa Cruz, que se aproveita da iluminação solar por ser uma estrutura aberta. 
Fotografia 01 - Palco-Altar do Rincão da Chácara Santa Cruz (Evandro Bonfim, 2010).

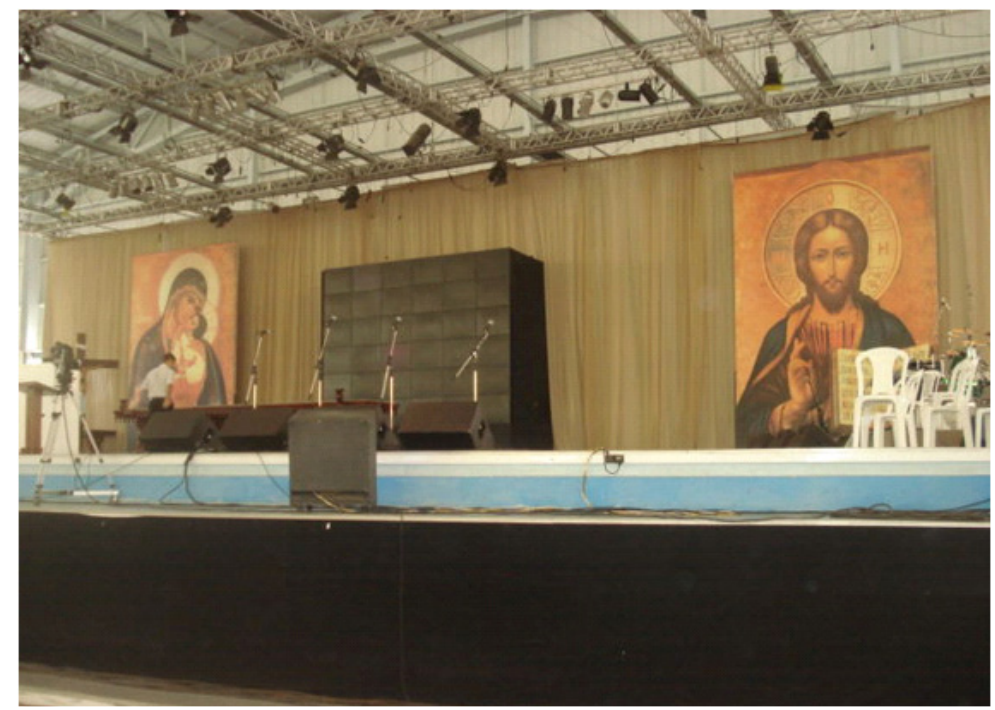

O cenário dos altares-palco segue a mesma harmonia cromática da estética bizantina, que privilegia as cores quentes, seguindo a cartela que vai do dourado ao marrom e tons de terra. Embora tal harmonia de matizes quentes seja funcional para a televisão, por proporcionar sensaçôes como acolhimento e ambiente caloroso, é preciso retomar a ideia de que a manifestação da cor dos pigmentos quentes usados pelos bizantinos são raios de luz divina que se irradiam a partir de ícones e mosaicos em direção às pessoas que os observam.

O esquema de luz do Auditório São Paulo (ASP), um ambiente fechado, demonstra bem tal noção de extravasamento luminoso. Nele, o posicionamento de duas das três luzes principais de estúdio, responsáveis pela iluminação de base dos cenários de televisão, se alinha com os ícones, conforme pode ser visto nas duas imagens a seguir. 
Fotografia 02 - Posicionamento de luz principal (refletores) no ASP (Evandro Bonfim,

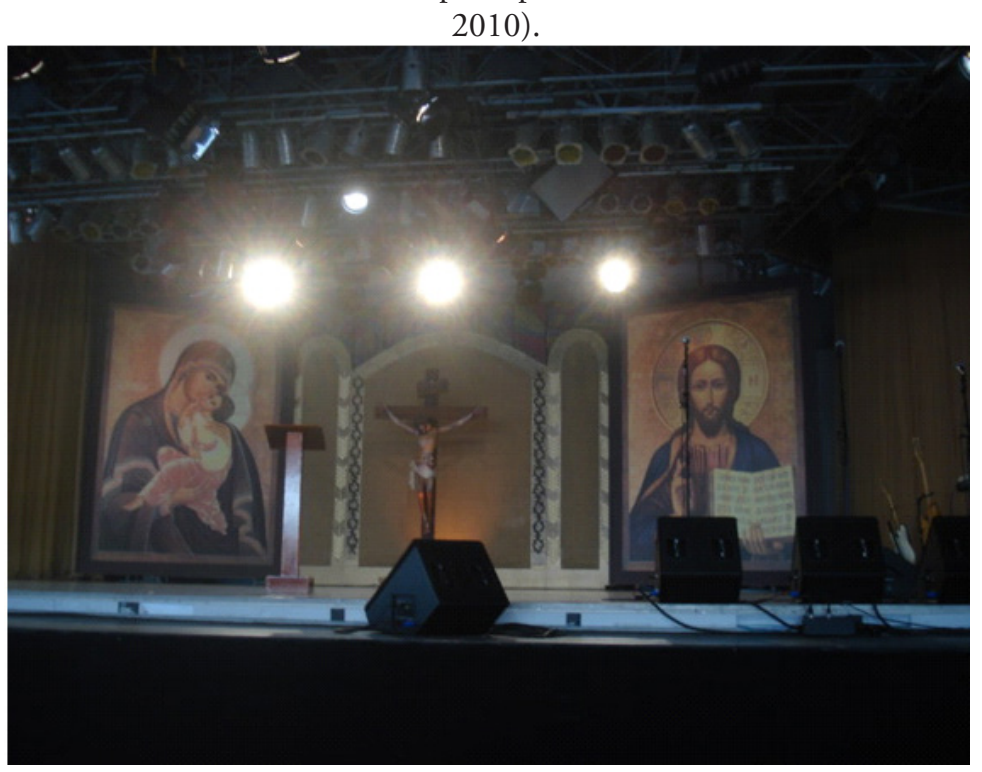

Fotografia 03 - Detalhe do alinhamento entre ícone e luz principal no ASP (Evandro Bonfim, 2010).

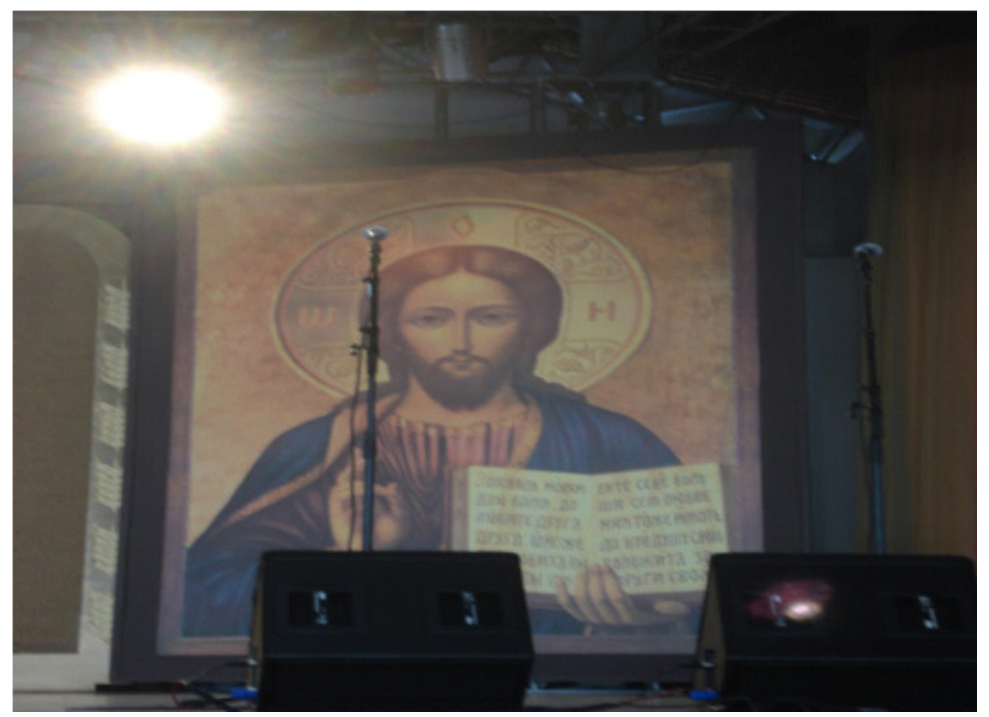

Debates do NER, Porto Alegre, ANo 2 I, N. 39, P. 263-292, JAN./JUl. 202 I 
A relação privilegiada entre observador e formas artísticas dependentes dos jogos de composição geométrica, luz e cor - como a pintura, a fotografia e o cinema - é a da imersão, em que o apreciador se transporta para dentro do objeto artístico, movimento de fortes conotaçôes subjetivas. Conforme visto, a arte bizantina promove justamente o contrário, pois o objeto artístico, como camada mais exterior do mundo divino, se projeta para dentro do observador, que é tomado pela exterioridade ao invés de exercitar a interioridade sugerida pela imersão.

A televisão, que é literalmente uma caixa que projeta luz (enquanto no cinema e na pintura a luz é recebida de forma indireta, refletida pela tela), parece reforçar a intenção bizantina de conseguir fazer a luz divina emanar, atingir e penetrar as pessoas, agora náo apenas através da cor dourada, mas de radiaçáo real transmitida pelo tubo de raios catódicos. A contiguidade do refletor com o painel-ícone, vista acima, mostra a coalescência entre a iluminaçáo divina e a iluminaçáo cênica, que são transmitidas para as pessoas através dos refletores, que têm como foco a plateia, e da mediação da TV enquanto objeto luminoso. É interessante que, enquanto os ícones têm destaque próprio no cenário televisivo-litúrgico da Canção Nova, a cruz obrigatória do altar precisa de uma luz focal, amarela e incidindo de baixo para cima a fim de causar a ilusáo ótica de maior tamanho da peça, para que esta possa se destacar no conjunto cênico, embora esteja aparentemente alinhada com o refletor central. O elemento que precisa ser marcado a fim de ser percebido é o católico, enquanto que o elemento bizantino está incorporado à proporção dos altares-palco.

Outro ponto interessante está na reprodutibilidade técnica do ícone. No mundo bizantino, a produçấo massiva de cópias dos ícones atendia à necessidade de dispersão das qualidades sagradas que determinada pessoa santa possuía e que permanecia inalterada ao se passar da materialidade corporal para a imagética. A reprodução fiel dos elementos do ícone original exigida pela tradição asseguraria que as cópias mantivessem as características também existentes na extensão não-corporal da mesma pessoalidade sagrada, garantindo, assim, a confecção em larga escala com manutenção das 
propriedades espirituais. Ou seja, sem afetar o que a teoria crítica da arte e da cultura de massas chamaria de "aura" (Benjamin, 2000). No contexto da Canção Nova, a difusão das imagens bizantinas ocorre sob a forma de painéis e cartazes (ícones magnificados) ou replicados eletronicamente através das imagens televisivas, que os capturam nas gravaçóes e os transmitem para os telespectadores da TV CN, ampliando a difusão dos ícones carismáticos.

Conforme comenta Herzfeld em artigo sobre o uso dos ícones nas áreas rurais de Creta, as referências bizantinas se contrastam com "West European constructions of individualism and the consequent elite disdain for copies, especially mass produced ones" (1990, p.120). Assim, a Canção Nova, seguindo tendências mais gerais do movimento carismático brasileiro (vide o Santuário do Terço Bizantino do padre Marcelo Rossi), se apropria de um estilo artístico antigo que estimula a reprodução massiva e a dispersão de elementos religiosos tão caros aos projetos evangelizadores da comunidade, que se define pela utilização dos recursos midiáticos para a realização da mesma empreitada.

Ao tomar como referência dominante a arte cristã fora do domínio latino, a comunidade realiza o movimento discursivo que Pêcheux (1988) chama de "desidentificação", visto que outra modalidade de reprodução massiva de imagens cristãs - as estátuas e os santinhos de papel do Catolicismo popular - não são promovidos diretamente pela Canção Nova, que procura desvincular sua marca desse tipo de peças. Nas lojas oficiais do grupo são vendidos pouquíssimos artigos originalmente religiosos, que são substituídos pelos produtos de mídia e algumas peças de vestuário e decoração. Tal restrição do que está disponível nas lojas Canção Nova se contrasta, por exemplo, com livrarias católicas que além de livros e discos também vendem desde hóstias até santos de gesso. No entanto, a contra identificação, ou seja, o rompimento completo com a matriz imagética católica não chega a acontecer. Isto porque, no âmbito da Chácara Santa Cruz, o grupo permite a existência de quiosques vendendo miudezas como terços, escapulários e crucifixos para atender a demanda dos peregrinos, que não são exclusivamente carismáticos. Mas mesmo nestes locais as imagens 
tridimensionais e os pequenos cartóes com figuras sagradas ligados aos costumes votivos estão ausentes. Dessa forma, o espaço da Canção Nova está dividido entre diversos regimes iconográficos e de produção de objetos religiosos que refletem o jogo discursivo da comunidade para mostrar o que a singulariza - no alcance semântico do qualificador "nova" - e, ainda assim, permanecer na chamada "unidade" católica.

\section{A POP ARTE CARISMÁTICA}

Ao tocar no ponto da reprodutibilidade técnica de imagens e objetos que guardam propriedades extraordinárias (artísticas ou sacras), pode se passar para outro estilo marcante da iconografia do grupo, a Pop Arte, que se alimenta precisamente da lógica e do material produzido exaustivamente pelos meios de comunicação e a cultura de massas para conformar as concepçôes estéticas que caracterizam o estilo.

Segundo McCarthy, a composição das peças de Pop Arte se vale de "cores brilhantes e desenhos simplificados", "montagem", "fontes fotográficas" "interesse por revistas em quadrinhos, por revistas de grande circulação e pelo cinema de Hollywood, que constituíam elementos importantes na formação da cultura visual desses artistas" (2002, p. 14). Tais elementos também são reconhecidos pelo público mais amplo, saturado pelo repertório de imagens, personagens e técnicas narrativas que compóem a discursividade dos meios de comunicação e da indústria do entretenimento.

As técnicas utilizadas pelos artistas que lidam com o pop também são extraídas dos espaços geradores de imagens para o consumo em larga escala, que eles tomam como referencial de trabalho.

A linguagem transparente da propaganda, que sugeria uma troca simples de dinheiro por gratificação, era familiar à maioria dos ocidentais nos anos 50 e 60 . Alguns artistas pop adotaram técnicas comerciais no ato de fazer seu trabalho. Em muitos trabalhos, incluindo-se Pincelada, de 1965, Roy Lichtenstein imitava a aparência de imagens baratas produzidas em massa 
através do uso de retícula, que em desenhos animados e anúncios serve para produzir meios-tons. Warhol, que entendia o mercado melhor que qualquer outro artista pop, praticamente abandonou a tradicional pintura de cavalete em 1962 para se concentrar na serigrafia (McCarthy, 2002, p. 32-34).

Em resultado, as obras de Pop Arte propóem arranjos iconográficos acessíveis para mais pessoas, pois conforme comenta o autor "as imagens eram localizadas o bastante em seu tempo para que náo se precisasse de uma formação clássica ou religiosa para reconhecer a iconografia" (McCarthy, 2002, p. 76). Tais preposiçóes são extremamente afins com as concepçóes da Canção Nova sobre a principal forma de agência cristã sobre o mundo, a evangelização. A comunidade se coloca o objetivo de transmitir o Espírito Santo e os conteúdos cristãos com certa urgência para o maior número possível de pessoas, em virtude das expectativas escatológicas do grupo. Os recursos midiáticos não atuam apenas como amplificadores do sistema de comunicação de dons e mensagens carismáticas, pois a discursividade que portam traz tanto a atualidade como o repertório icônico popular do qual a comunidade vai se servir para montar as imagens com as quais procura tocar as audiências para as quais se dirige.

A colagem é uma das estratégias mais utilizadas pela Pop Arte desde os trabalhos considerados pioneiros do estilo, como "O que exatamente torna os lares de hoje tão diferentes, tão atraentes?", feita por Richard Hamilton em 1956. A maior parte das peças decorativas dos ambientes da Canção Nova podem ser consideradas obras (não-intencionais?) de Pop Arte religiosa usando a técnica de colagem realizada digitalmente através da sobreposição de imagens, conforme pode ser visto no mural abaixo que decora vários estúdios e salas da Rádio Canção Nova do Rio de Janeiro: 
Fotografia 04 - Montagem adesivada nas dependências da Rádio Canção Nova RJ (Evandro Bonfim, 2010).

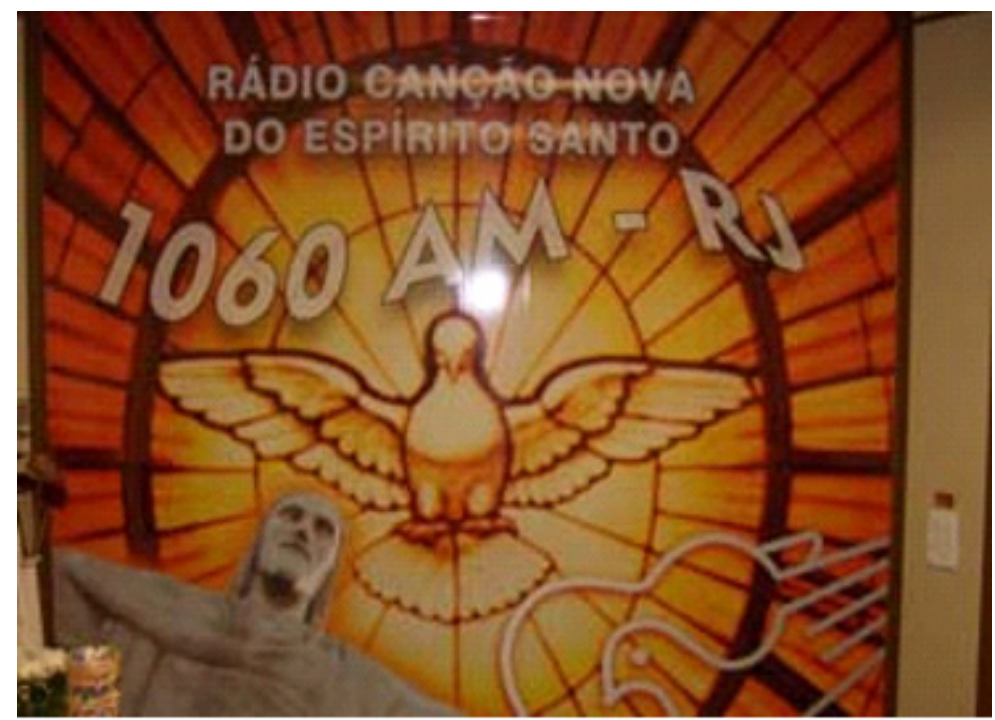

A base da montagem é uma obra de arte clássica, cuja identificação por parte do observador não se faz necessária, segundo os preceitos da Pop Arte. No entanto, como operador discursivo, o plano de fundo onde vão ser inseridas as unidades visuais representando a Canção Nova no Rio de Janeiro não poderia ser mais significativo. Trata-se do detalhe de um vitral do altar-mor da Basílica de São Pedro no Vaticano, destacando o símbolo do Espírito Santo, a pomba. Tal símbolo pode ser considerado o único que deve obrigatoriamente ser reconhecido por quem aprecia a obra, visto que a posse da codificação (reconhecer no animal alado a manifestação paraclética) implica na própria passagem para o âmbito da espiritualidade carismática/ pentecostal. A base (a arte clássica do Vaticano) se mostra ambivalente visto que serve tanto de fundamento como segundo plano em relação aos demais elementos, que parecem se projetar como formas mais atuais do que está contido na trama dos vitrais renascentistas.

No primeiro plano temos o elemento que simboliza a cidade do Rio de Janeiro, o Cristo Redentor, imagem que já carrega em si o status de 
obra pop religiosa, e a logomarca da Canção Nova, composição visual proveniente do design comercial. $\mathrm{O}$ último elemento da montagem são os dados sobre a rádio, escritos em caixa alta de fonte sem serifa, técnica de design usada para atrair a atenção para pequenos textos. O prefixo da rádio conta com um efeito extra para a fonte, a ondulaçáo que remete tanto às ondas das amplitudes médias quanto ao sopro pneumático propiciado pela programação da emissora.

A colocação destes três elementos na base que remete à instituição católica de longa data corresponde ao gesto discursivo que será chamado aqui de atualização. $\mathrm{Na}$ atualizaçáo, o novo desliza para o antigo, tornando-o contemporâneo. Para reforçar a natureza da produçáo de sentidos envolvida na atualizaçáo, pode-se comparar a imagem acima com a seguinte imagem nấo-religiosa, correspondente a um frame do filme Marie Antoinette (2006), de Sofia Coppola.

Fotografia 05 - Frame de Marie Antoinette (2006) (Google Images, 2010).

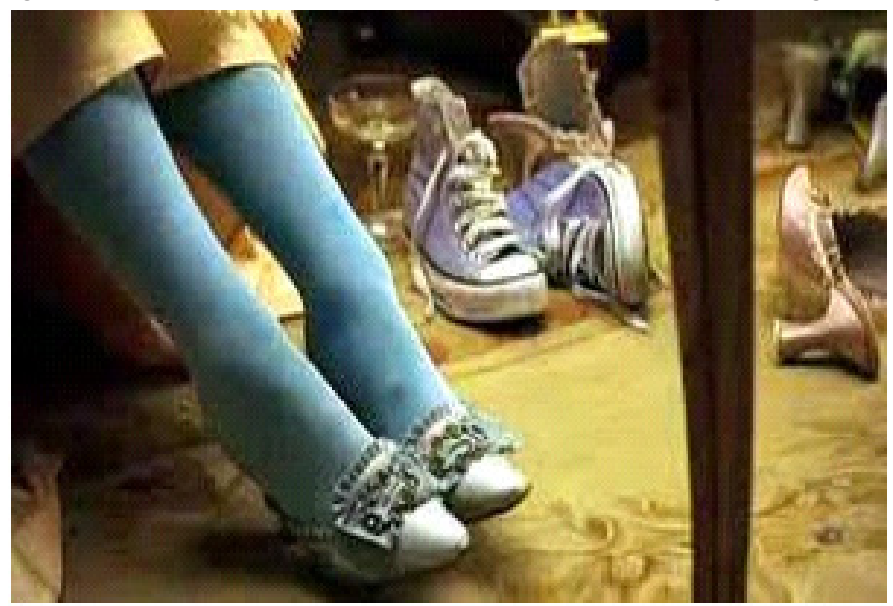

O filme pretende tratar a personagem histórica envolvida nos graves acontecimentos que culminaram na Revoluçáo Francesa, como uma adolescente que gosta de moda, festas e vida expansiva, mas tem que se confrontar com as exigências do protocolo real e da política interna e externa dos

Debates do NER, Porto Alegre, ANo 21, N. 39, P. 263-292, JAN./Jul. 202 I 
Bourbon. Para mostrar o lado jovial e sensível da princesa austríaca que se tornará rainha da França, a diretora se vale de elementos pop, como substituir a trilha sonora instrumental clássica, condizente com os ambientes da corte, por rock alternativo. A mesma orientação é tomada por Milena Canonero, responsável pelos figurinos, que não apenas recupera os trajes de Versailles à época, mas introduz novidades do mundo contemporâneo em meio ao estilo de Maria Antonieta, produzindo justamente o efeito de sentido que torna a personagem atual. O quadro cinematográfico acima mostra as pernas da rainha que acaba de se calçar, tendo preferido um modelo clássico ao tênis all star, calçado considerado ícone pop de juventude e descompromisso.

Tanto o tênis quanto a logomarca, o prefixo da rádio e o Cristo Redentor, são elementos visuais pertencentes a uma iconografia pop, ligada ao repertório imagético dos meios de comunicação de massa e da produção de bens de consumo para a vida urbana, distantes, portanto, dos ambientes icônicos onde estáo inseridos (barroco para o filme, renascentista para o adesivo). Tal inserção acrescenta informaçáo nova à retomada dos discursos visuais antigos, se mostrando afim com a noção de comentário como estratégia discursiva discutida por Foucault. Segundo o autor, no comentário

o desnível entre o texto primeiro e o texto segundo desempenha dois papéis que são solidários. Por um lado, permite construir (e indefinidamente) novos discursos: o fato de o texto primeiro pairar acima, sua permanência, seu estatuto de discurso sempre reatualizável, o sentido múltiplo ou oculto de que passa a ser detentor, a reticência e a riqueza essenciais que lhe atribuímos, tudo isso funda uma possibilidade aberta de falar. Mas, por outro lado, o comentário não tem outro papel, sejam quais forem as técnicas empregadas, senão o de dizer enfim o que já estava articulado silenciosamente no texto primeiro (Foucault, 2009 [1971]), p.25).

Com o foco agora somente na peça Canção Nova, pode-se considerar que os elementos inseridos possuem os traços [+ atual] e [+ profano], enquanto a base se caracteriza por ser [- atual] e [- profano] (ou [+ sagrado]). O traço [+ atual] se espalha para a base, o discurso cristáo católico, tornando-o 
contemporâneo. i.e., relevante para as pessoas da época presente, pois este agora se mostra capaz de lidar não somente com referências tradicionais, visto que passa a incluir visualidades mais próximas dos observadores: localizadas no lugar onde vivem (o Cristo Redentor, índice também de inculturação), no ambiente mercadológico onde trabalham (a logomarca) e nos recursos midiáticos onde procuram diversão e informação (o prefixo da rádio).

No segundo movimento, o traço [+ sagrado], proveniente da autoridade contida no texto primeiro, se espalha para os elementos inseridos, tornando-os além de novos, extraordinários, garantindo com que a sacralidade esteja presente naquela rádio, na Canção Nova e na cidade do Rio de Janeiro. Com a base fornecida pela visualidade de referência, o comentário realizado pela Canção Nova promove a relação entre formas visuais pretéritas, cujo sagrado contido em si parece estar inoperante diante das condiçóes recentes do mundo, e as formas atuais, que podem reativar as propriedades do texto primeiro por engatilhar a transferência de potência espiritual.

Outro exemplo de peça pop encontrada nas dependências da Canção Nova, no caso do Centro de Acolhida ao Visitante da Chácara Santa Cruz, pode ser visto abaixo: 
Fotografia 06 - Display com os Fundadores da Comunidade (Evandro Bonfim, 2010).

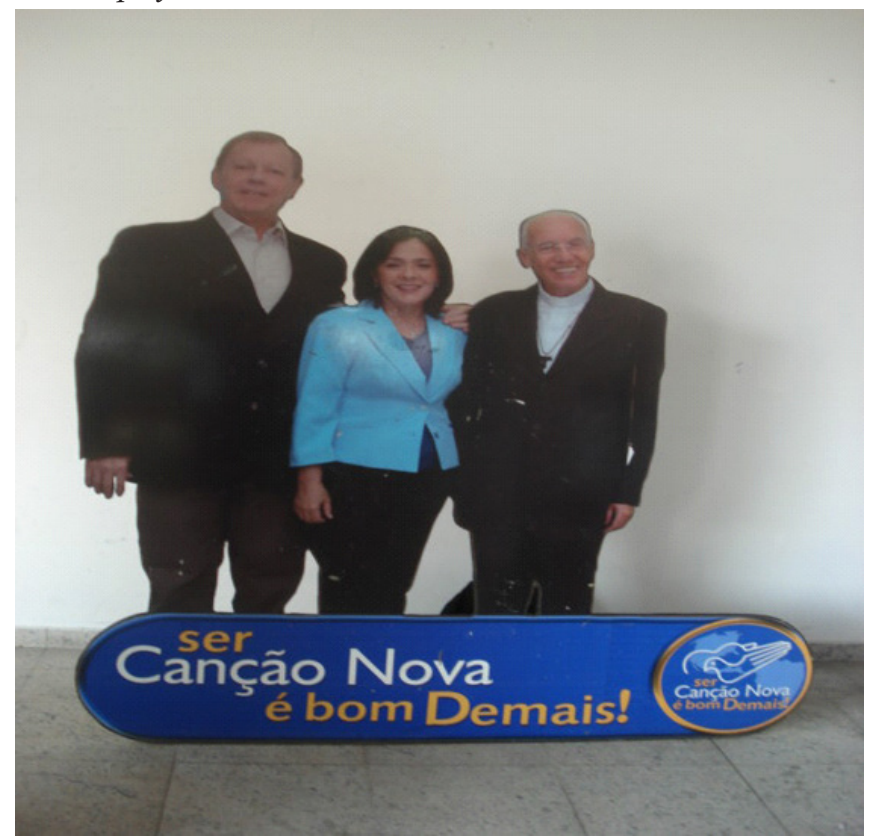

A estrutura que contém o retrato dos três fundadores da comunidade (da direita para a esquerda, padre Jonas Abib, Luzia Santiago e Wellington Jardim) chama-se display, dispositivo usado em publicidade que consiste em uma base fixa ou móvel onde se afixa imagens relativas ao produto que se deseja promover. Assim, o suporte do discurso visual, como o design da logomarca, é um elemento extraído do sistema de produção de imagens em que se apoia o mercado publicitário, visando a promoção do consumo.

O que está contido no display é um tipo de imagem bastante familiar na tradição católica, uma trindade. No entanto, de maneira diferente da Santíssima Trindade ou da Sagrada Família, a tríade em questão é mista. Somente padre Jonas Abib possui sacralidade referendada pela Igreja Católica. Os outros dois membros sáo considerados leigos em termos oficiais. Em última instância, possuem o mesmo estatuto espiritual dos demais peregrinos que visitam Cachoeira Paulista. Porém, estão aptos a figurar ao lado de uma 
autoridade eclesiástica como responsáveis por uma coletividade dentro do Catolicismo, propondo assim um tipo novo de configuraçáo social para aquele Cristianismo específico, baseado no critério carismático. $\mathrm{O}$ rodapé da imagem é um dos slogans da comunidade, que está co-referenciado com os sorrisos dos três fundadores: “Ser Canção Nova é bom demais!”. O slogan é repetido no próprio rodapé dentro de um círculo contendo a logomarca da Canção Nova e parte do mapa-múndi. Este elemento também tem como base materiais promocionais da própria comunidade, como adesivos para carros, composto pelo mesmo arranjo slogan/mapa/logo.

A utilização de suportes para material visual do mercado publicitário se mostra a principal forma de dispor a iconografia do grupo por toda a Chácara Santa Cruz. Outro exemplo interessante são as boas-vindas dadas aos visitantes sob a forma de mídia exterior ou outdoor:

Fotografia 07 - Outdoor de boas-vindas (Evandro Bonfim, 2010).

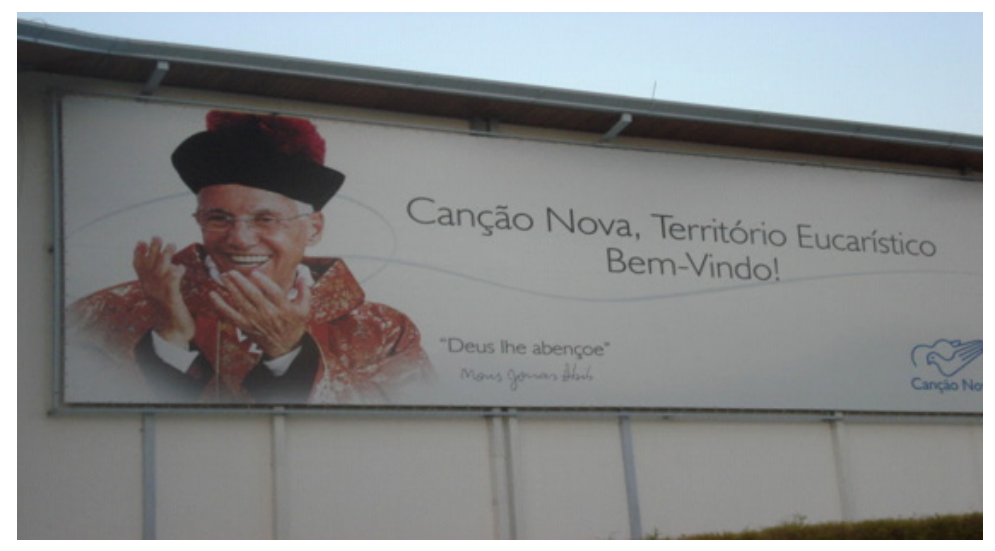

O outdoor é crucial para a promoção da noção de espaço da Canção Nova, o território eucarístico (ver mais detalhes sobre a espacialidade Cançâo Nova, sobretudo da Chácara Santa Cruz em Bonfim, 2012, e Oliveira, 2016). A logomarca da Canção Nova está novamente presente, em obediência ao princípio da identidade visual, que será discutido mais à frente. A porção de comentário está nas próprias vestes purpúreas do padre Jonas Abib, no 
esteio da recuperação dos paramentos litúrgicos promovidos pela Renovação Carismática de forma mais ampla. No entanto, se está no regime discursivo demonstrado acima, em que a autoridade dos recursos visuais clássicos (como o barrete com o tufo vermelho e a capa solene), se mostra ativa por se combinar com elementos da visualidade contemporânea (o suporte visual e a marca de identidade institucional).

Grande parte da economia iconográfica da Canção Nova, conforme sugerido nos exemplos acima, segue os princípios de organização visual não da arte religiosa clássica nem do culto católico popular, mas dos princípios de design utilizados em projetos de sinalização ambiental (para parques, vilas olímpicas), projetos gráficos de mídias impressas e eletrônicas e programação visual corporativa. $\mathrm{O}$ tema mereceria o exame detalhado de todos os elementos visuais encontrados na Chácara Santa Cruz, que a torna apta para o acolhimento e circulação de multidóes que estáo o tempo todo sendo reiteradas sobre o espaço onde estão: o território eucarístico da comunidade Canção Nova (que se mostra também carismático e católico). Como a tarefa conduziria a análise para questôes extremamente técnicas, gostaria de comentar apenas dois princípios de design largamente utilizados pelo grupo que o permitem produzir os efeitos de sentido da Pop Arte que estamos comentando: a identidade visual e a repetição.

$\mathrm{Na}$ verdade, os dois princípios são interligados, pois a principal maneira de se promover a identidade visual de determinado projeto de comunicaçáo ou âmbito corporativo é através da repetição dos elementos do design. Williams define assim o princípio da repetição:

O princípio da repetição afirma que algum aspecto do design deve se repetir no material inteiro. O elemento repetitivo pode ser uma fonte em bold (negrito), um fio (linha) grosso, algum sinal de tópico, um elemento do design, algum formato específico, relaçôes espaciais. (...) Pode ser qualquer item que o leitor reconheça visualmente. A repetição pode ser considerada como consistência. Ao olhar para um jornal de oito páginas, é justamente a repetição de alguns elementos - sua consistência - que faz com que cada uma dessas oito páginas 
pertença ao mesmo jornal. Se a página 7 não contiver elementos repetitivos trazidos da página 6 , o jornal inteiro perderá sua aparência coesa. A repetição, porém vai além da simples consistência: é um esforço consciente para unificar todos os elementos do design (Williams, 2006, p. 49).

Os elementos de repetição mais utilizados na Canção Nova, conforme visto nas duas últimas imagens, são a logomarca do grupo e a harmonia baseada no azul, com tons quentes de contraste. Mas qual o funcionamento discursivo de tal princípio do design dentro da iconografia do grupo? $\mathrm{O}$ seguinte arranjo visual ilustra bem a possível resposta à questáo:

Fotografia 08 - O cruzeiro dos acampamentos (Evandro Bonfim, 2010).

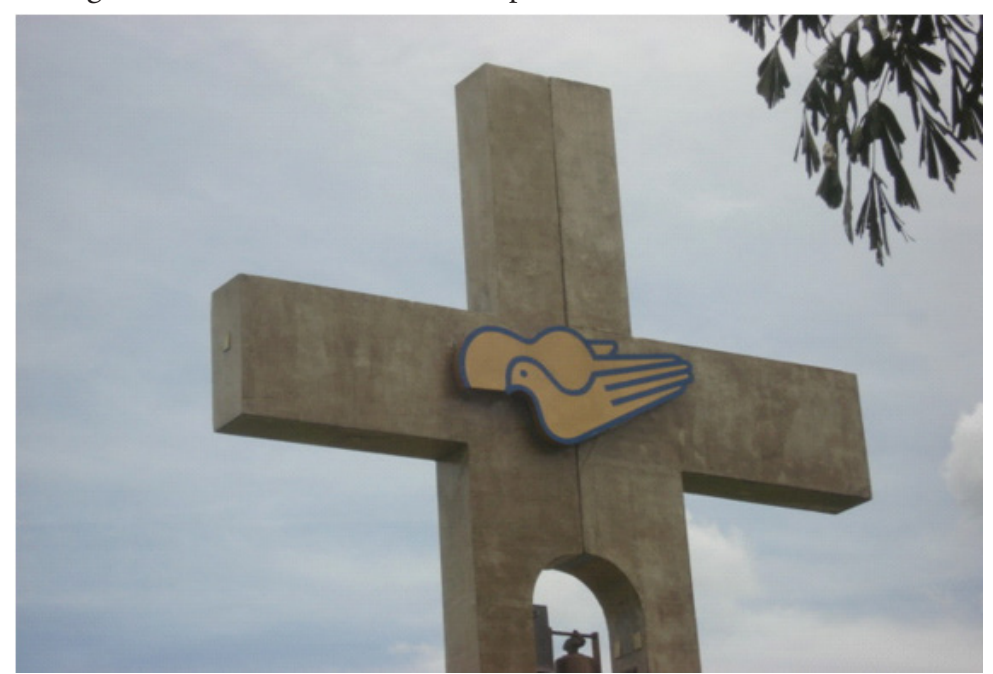

A imagem mostra o cruzeiro erguido na área onde os peregrinos montam as barracas para os Acampamentos de Oração. O posicionamento se mostra significativo visto que a cruz de Cristo substituiria o poste com a serpente de bronze que protegia o acampamento israelita (Números 21, João 3. Ver Baumann e Soares, 1995, para efeito de sentido similar mediante a fixação do curuzu em aldeamentos jesuítas, aproveitando-se da tradição dos postes contra maus espíritos em aldeias indígenas). Os cruzeiros são monumentos 
colocados em igrejas, cemitérios, praças, nas partes mais altas das cidades ou mesmo em estradas como marcos da fixação do Cristianismo em determinado território ou como referência de navegação entre diversos espaços cristãos ligados à devoção e memória. A base dos cruzeiros, que liga o eixo vertical da cruz à terra, pode ser estilizada sob a forma de colunas apoiadas em degraus, pedestais ou outras soluçóes arquitetônicas. No entanto, a cruz em si costuma ser despida de elementos extras, admitindo somente o próprio crucificado. A cruz com o Cristo (crucifixo), no entanto, não se mostra tão frequente quanto a cruz simples.

No cruzeiro da Canção Nova, tem-se a base estilizada com sinos, mas o mais interessante está no meio da cruz. Onde deveria estar o espaço vazio ou ocupado pelo corpo do Cristo está a logomarca da Canção Nova. Novamente, tem-se o gesto discursivo que está sendo perseguido ao longo da discussão sobre Pop Arte, em que o elemento iconográfico novo desliza para a base iconográfica antiga, tornando-a contemporânea. No entanto, parece ocorrer ainda outra forma de deslizamento, que pode ser qualificada como sobreposição/substituição icônica, mas também como iconoclash, nos termos de Bruno Latour (2008), pois aquele espaço vazio na cruz está preenchido pela proposta de Cristianismo da Canção Nova, que enfatiza a Era do Espírito Santo depois da Era do Cristo, iconograficamente marcada pela pomba no lugar do corpo martirizado.

O princípio da repetição faz com que a marca de identidade visual da Canção Nova domine o ambiente, tornando a égide da comunidade e do Cristianismo pneumático reconhecível em todos os suportes visuais, tanto os tomados de empréstimo ao patrimônio católico quanto da comunicação publicitária. O que costura justamente as duas fontes de referências (unifica, torna coeso, confere consistência, nos termos do design) é precisamente o fato de que ambos os elementos visuais do coletivo carismático estão presentes, criando os elos discursivos entre atualidade e tradição/singular e massivo/ extraordinário e cotidiano. 


\section{À GUISA DE CONCLUSÃO}

No decorrer do artigo, foram apresentadas as duas principais referências artísticas formativas do discurso visual Canção Nova: o estilo Bizantino e a Pop Arte. Ambos se ligam entre si e com a comunidade carismática brasileira ao tomar como questão constitutiva o tema da reprodutibilidade técnica. A arte de Bizâncio concebe a pessoa como distribuída em inúmeras materialidades, tornando a dispersão das propriedades sagradas possível através da cópia de imagens que originalmente não foram feitas por mãos humanas. A Arte Pop se apropria das imagens e das técnicas produzidas pelos meios de comunicaçáo, o mercado publicitário e a indústria do entretenimento para criar obras que compartilhem do repertório imagético do público contemporâneo, cuja formação visual passa por tais veículos mais do que instituiçôes formais como museus. A Canção Nova faz movimento similar às duas escolas artísticas ao utilizar formas midiáticas (imagéticas, narrativas e estruturais, em suma, a discursividade delas) para a comunicação de conteúdos cristãos e de pessoas divinas.

Assim como a arte Bizantina lidava com a nova situação comunicativa do Cristianismo, que deveria se dirigir às multidóes do Império Romano recém unificado por Constantino, a Canção Nova reconhece como público a ser evangelizado não grupos específicos, mas as massas atingidas pelos meios de comunicação, acessíveis apenas se os recursos de transmissão de mensagens e concepçóes visuais destes forem levados em conta na evangelização que antecede ao clímax escatológico. A Canção Nova encontra na arte Bizantina os princípios para que a transmissão vá além da aquisição de informaçóes bíblicas e doutrinárias e se torne experiência espiritual, visto que tanto o ícone bizantino como os programas da comunidade intentam a transferência de pessoas divinas para os observadores.

Já na Arte Pop a comunidade busca técnicas de composição, como a montagem para a efetuação do gesto discursivo denominado aqui de atualização, em que novos ícones vão reativar as bases imagéticas tradicionais a fim de tornar a mensagem cristã contemporânea e relevante para as 
assistências formadas pela iconologia procedente de fontes como cinema, televisão, publicidade, revistas e internet. As relaçóes entre os dois estilos artísticos e o coletivo carismático foram demonstradas mediante a análise do discurso presente nos suportes visuais híbridos que funcionam como pinacoteca para a iconografia Canção Nova, a saber, os altares-palcos, displays, cruzeiros, painéis e adesivos.

\section{REFERENCIAS}

BAUMANN, Teresa; SOARES, Marília Facó. A construção do outro através do uso da lingua indigena: o teatro de Anchieta. Actes: la "découvert" des langues et des écritures d'Amérique, 1995.

BENJAMIN, Walter. A obra de arte na era da reprodutibilidade técnica. In: LIMA, Luiz Costa. Teoria da Cultura de Massa. Rio de Janeiro: Paz e Terra, 2000.

BESANÇON, Alain. A Imagem Proibida. Uma história intelectual da iconoclastia. Rio de Janeiro: Bertrand Brasil, 1997.

BIALECKI, Jon; DAWANI, Girishi. "Introduction: What is an Individual?. The view from Christianity. Hau: Journal of Ethnographic Theory 5 (1), p. 271-294, 2015.

BONFIM, Evandro. Canção Nova: Circulação de dons, mensagens e pessoas espirituais em uma comunidade carismática. Rio de Janeiro: Tese de Doutorado em Antropologia Social, Museu Nacional, UFRJ, 2012.

BONFIM, Evandro. Glossolalia and Linguistic Alterity. The Ontology of Ineffable Speech. Religion and Society. Advances in Research 6, p.75-89, 2015.

BONFIM, Evandro. Das Relaçôes entre Exemplo e Parresia: Formas de Evangelelização Católica. Religião e Sociedade 36 (2), p.71-84, 2016.

CSORDAS, Thomas. The Sacred Self. A Cultural Phenomenology of Charismatic Healing. Berkley: University of California Press, 1997a. 
CSORDAS, Thomas. Language, Charisma and Creativity: the ritual life of a religious movement. Berkley: University of California Press, 1997b.

DUMONT, Louis. Do Indivíduo-fora-do-Mundo ao Indivíduo-no-Mundo. In: Individualismo: uma perspectiva antropológica da ideologia moderna. Rio de Janeiro: Rocco, 2000.

FOUCAULT, Michel. A Ordem do Discurso. São Paulo: Loyola, 2009.

GOMBRICH, Ernest. A História da Arte. Rio de Janeiro: LTC, 1999.

HERZFELD, Michel. Icons and Identity: Religious Orthodoxy and Social Practice in Rural Crete. Anthropological Quarterly Vol. 63 Issue 3, p. 109-121, 1990.

LATOUR, Bruno. "Não Congelarás a Imagem" ou como não desentender o debate entre a religiáo e a ciência. Mana. Estudos de Antropologia Social, vol. 10, n 2, p. 349-375, 2004.

LATOUR, Bruno. O que é um Iconoclash? Ou há um mundo além das guerras de imagem? Horizontes Antropológicos Ano 14, № 29, p. 111-150, 2008.

MAUSS, Marcel. Uma categoria do espírito humano: a noçáo de pessoa, a de "eu". In: Sociologia e Antropologia. São Paulo: Cosac Naify, 2003.

McCARTHY, David. Arte Pop. São Paulo: Cosac Naify, 2002.

OLIVEIRA, Jefferson Rodrigues de. Canção Nova e as Peregrinaçôes Pós-Modernas. Hierópolis de Cachoeira Paulista-SP. Paco Editoria, São Paulo, 2016. PANOFSKY, Erwin. Arquitetura Gótica e Escolástica. São Paulo: Martins Fontes, 2001.

PÊCHEUX, M. Semântica e Discurso. Campinas: UNICAMP Editora, 1988. ROBBINS, Joel. Becoming Sinners: Christianity and Moral Torment in a Papua New Guinea Society. Berkeley: University of California Press, 2004. 
VILAÇA, Aparecida. Conversão, predação e perspectiva. Mana. Estudos de Antropologia Social 14 (1), p. 173-204, 2008.

WILLIAMS, Robin. Design para quem não é designer. São Paulo: Callis, 2006.

Recebido em: 31/08/2020

Aprovado em: 27/04/2021 